\begin{tabular}{|c|c|}
\hline \multirow{3}{*}{ 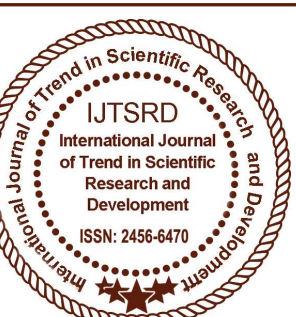 } & $\begin{array}{l}\text { International Journal of Trend in Scientific } \\
\text { Research and Development (IJTSRD) }\end{array}$ \\
\hline & International Open Access Journal \\
\hline & ISSN No: $2456-6470$ | www.ijtsrd.com | Volume - 2 | Issue - 1 \\
\hline
\end{tabular}

\title{
An Evaluation of Structuring in Nigeria: Marxian Perspective
}

\author{
Jamilu Ibrahim Mukhtar \\ Department of Sociology, Federal University Dutse, \\ PMB 7156, Jigawa State, Nigeria \\ Jamilu Abdulhamid Bello \\ RMK, College of Arts, Sciences and Remedial
Studies, Tudun Wada Kano, Kano State
}

\begin{abstract}
The aim of this paper is to discuss restructuring of the Nigeria in the light of Marxian Dialectical and Historical Materialism. The paper used secondary qualitative data from the literature (books, newspapers, dictionary, and conference proceedings) that dealt with the concept of restructuring, the essence of restructuring in Nigeria, and the works of Karl Marx, particularly ideas related to the Dialectical and Historical Materialism. The paper examined the political economy of the restructuring in Nigeria using the Dialectical and Historical Materialism and it found that the yearning for the structuring is logical struggle because of the long standing exploitation and alienation of the various States of the Federation by relying on Federal allocation. Therefore, the paper concluded that the deplorable condition of the State Governments is a metaphor of the Marx's political economy of the exploitative relationship between the capitalist and workers.
\end{abstract}

Keywords: Dialectical and Historical Materialism, Political Economy, Restructuring Nigeria

\author{
Abdullahi Yusuf Ahmad \\ RMK, College of Arts, Sciences and Remedial \\ Studies, Tudun Wada Kano, Kano State \\ Nuhu Musa Hanga \\ RMK, College of Arts, Sciences and Remedial \\ Studies, Tudun Wada Kano, Kano State
}

\section{Introduction}

The Nigerian political economy can be understood and explained depending on the disciplinary orientation and bias of the analyst. But there is no any best way to make such analysis other than the area of the "Political Economy" itself. Although are numerous issues that should attract intellectual discourse in the Nigerian political economy, this paper will discuss restructuring of the Nigeria in the light of Marxian Dialectical and Historical Materialism. For about two decades now, agitation for restructuring Nigeria has been on the increase by individuals and groups from across the various geo-political regions of the country. Restructuring is viewed from different perspectives. Some Nigerians, commonly those from the southern part of the country consider it as a necessary move towards national, geopolitical and individual states' development. Others, mostly northerners, view it as a recipe for the retrogression of some states and promoting some states at the detriment of others.

Restructuring is needed in Nigeria in order to sanitize the body polity. As some pro-Libyan revolution like Ambatek (2011) note, the revolution was necessary in order to fight the pervasive corruption there through the 
corrupt practices discouraging systems, such as capacity building and restructuring. Therefore, restructuring is a viable journey to effectively fight corruption in Nigeria, too. However, other contrary views are also valid to the apologists of the federalism. This is because some northerners are afraid that the restructuring will be left many northern Nigerian states dominated despite their larger population size compared with the other states within the federation.

In view of this background remark, the paper will examine the restructuring of Nigeria using the Marx's dialectical and historical materialism.

\section{The Concept of Structuring}

By way of definition, "structure" can be seen as the subsystem or functional component that works alongside others to make up the whole system. The complex system governs the inter-relationship between the components or units to ensure their harmonious symphony seamless to achieve a common purpose or a given output (Bello, 2017). Restructuring, on the other hand, means different things to different people. This is why Bello (2017) commented that various people and groups are agitating for restructuring in Nigeria, but none of them clarified specifically what they meant by the term "restructuring".

Literally, restructuring means "the process or an instance of changing the way in which something is organized or arranged" (Encarta Dictionary, 2009). In the Nigerian context, Aziken, Akinrefon, Dapo \& Kumolu (2017) take their view of restructuring from its leading advocates and public figures, i.e. Former President Ibrahim Badamasi Babangida and Former Vice-President Atiku Abubakar. Corroborating the Babangida's notion of restructuring Aziken et al. (2017) defined it as the devolution of powers to the extent that more responsibilities are given to the states while the Federal Government is vested with the responsibility to oversee the foreign policy, defense and the economy of the nation (Nigeria, in this case). Added to this, Aziken et al. (2017) note that restructuring also involves the desire to introduce state police across the states of the Federation as well as revisiting the idea of having Federal roads in towns and cities.

\section{Dialectical and Historical Materialism}

Whenever dialectical and historical materialism or the concept of political economy is mention, the next that comes to mind is the sociological theorist and a political philosopher, Karl Marx (1818-1883). The concept of dialectics, according to Elster (1986), has been used with a number of meanings. Common to almost all is the view that conflict, antagonism, or contradiction is a necessary condition for achieving certain results. Contradiction between ideas may be a condition for reaching truth; conflict among individuals, classes, or nations may be a necessary condition for social change. This preliminary remark suggests a distinction between a dialectical method and a dialectical process, between dialectics as a feature of our thinking about the world and dialectics as a feature of the world itself. On a certain conception of dialectics, these are not alternative conceptions but complementary ones. The dialectical method reflects the dialectical character of the world.

Among other contributions, Marx is credited for expounding and elaboration of the conflict model of society, specifically the theory of social change based upon antagonisms between social classes; the insight that power originates primarily in economic production; that the system of capitalism entails some contradictions which will lead to its collapse in favour of socialism or communism. Dialectical and historical materialism is a Marxist idea that traced the struggle between the dominant competing classes in various historical societies till the capitalist era. That is why Karl Marx is well known and celebrated for his "Dialectical and Historical Materialist" idea.

In line with the above, Elwell (2012) states that Marx's vision was based on an evolutionary point of departure. Society was comprised of a moving balance of antithetical forces that generate social change by their tension and struggle. For Marx, human history is defined by class struggle (Guclu, 2014). Marx \& Engels (1967/1848: 8) further explained that the histories of all societies are based on class struggles between those who are exploited and those who are exploiting them. 
In their opening remark of their work, Manifesto of the Communist Party Marx \& Engels contended that:

The history of all hitherto existing society is the history of class struggles. Freeman and slave, patrician and plebeian, lord and serf, guild-master and journeyman, in a word, oppressor and oppressed, stood in constant opposition to one another, carried on an uninterrupted, now hidden, now open fight, a fight that each time ended, either in a revolutionary reconstitution of society at large, or in the common ruin of the contending classes. (p. 1).

In their reflection of the pervious social arrangements, Marx \& Engels (1967) noted that in the earlier epochs of history, there used to be a complicated arrangement of society into various orders, a manifold gradation of social rank. In ancient Rome we have patricians, knights, plebeians, slaves; in the Middle Ages, feudal lords, vassals, guild-masters, journeymen, apprentices, serfs; in almost all of these classes, again, subordinate gradations. The modern bourgeois society that has sprouted from the ruins of feudal society has not done away with class antagonisms. It has established new classes, new conditions of oppression, and new forms of struggle in place of the old ones.

\section{An Evaluation of Restructuring of the Nigeria Using Marxist Dialectical Materialism}

Restructuring is a policy that applies to national politics and organizational settings. Various organizations resort to restructuring when they face downfall or when they are affected by economic depression or recession. They usually do that through downsizing or layoffs of employees. At the organizational level, as much as at the national level, restructuring has both its advantages and disadvantages. But the focal concern of the paper is on the constitutional arrangement, which in Nigeria is part of the federal system of government.

The federal system of government in Nigeria (federalism) simply refers to that government in which governmental powers that exists in the country are shared between a central government that represent the whole country and the government of component regions or states so that each government is legally and constitutionally independent and autonomous. There are also three arms or organs of government namely: the legislature, executive and the judiciary (Anazor, 2011). The legislature is the law initiating body; the executive puts the law into work or implementation and the judiciary interprets the law. The restructuring according to majority of its advocates in Nigeria is to provide autonomy to the respective states, to be independent of the interference of the federal government.

Restructuring has been the current buzzword in the Nigerian political lexicon. Both political and nonpolitical actors are pushing forward their ideas about the restructuring in Nigeria, its predisposing factors and possible social, economic and political implications on the fate of the nation. However, the focus of this paper is to explain the restructuring from the perspective of political economy of the Marxism, it is helpful to understand More than that It is the conflict between the dominating class and those they dominate; superiors and subordinates, oppressors and oppressed, bourgeoisie and proletariat, etc.

Using the Marxian political economy theory, one easily demystify the exploitative nature of the present state of the Nigeria's Federal level which alienates the various states through, and the state governments exploiting the Local Government Areas through joint account scheme. In view of the above, Atiku Abubakar once said that "there is no doubt that many states are not viable, and were not viable from the start once you take away the federation allocations from Abuja". Therefore, we have to find creative ways to make them viable in a changed federal system. The best and essential alternative for Abubakar (2017) is to devolve more powers and resources from the federal government and deemphasise federal allocations as the source of sustenance of states.

\section{Conclusion}

The paper evaluated the political economy of the restructuring in Nigeria using the Marxist political economy theory. To do this, the dialectical and historical materialism was employed to make this analysis. The paper found that the yearning for the structuring is logical struggle because of the long 
standing exploitation and alienation of the various States of the Federation by relying on Federal allocation. In conclusion the deplorable condition of the State Governments is a metaphor of the Marx's political economy of the exploitative relationship between the capitalist and workers. The same problem is affecting the local government areas, which are exploited by the state governments through joint account scheme. Therefore, restructuring is a welcome development if it will mean a movement towards making each state to stride to achieve development irrespective of the interference and intercession of the federal government.

Although the paper has offered some insights into the concept of restructuring and evaluated it using the Marxist theory, it still has some limitations. First, it did not evaluate the restructuring using other theories, such as structural-functionalism. Failure to do that was conditioned by the prediction that the other theory will also support the restructuring by virtue of its functional determinism, but it can also refute Marxism because of its integrative determinism. Second, bring any anecdotal evidence of the restructuring in other countries, in order to justify the conclusion for the advantage of the restructuring in Nigeria. Third, the paper did not involve any empirical data from the agitators of the restructuring in Nigeria. Fourth, the paper emphasises the positives or advantages of restructuring in Nigeria and ignored its negatives or disadvantages. In view of these limitations, the paper suggested for further study in order to establish the practical relevance of restructuring in Nigeria for the benefit of academic community and policy makers.

\section{REFERENCE:}

1. Abuakar, A. (30 June, 2017). "Nigeria: What is restructuring?" Vanguard. Retrieved from: www.vanguardngr.com/2017/06/nigeriawhat-is-restructuring/ (10/11/2017).

2. Ambarek, S. (2011). Beyond Gaddafi: Libya's Governance Context. The Governance Network ${ }^{\mathrm{TM}}$

3. Anazor,E. C. (2011). Good leadership and governance in Nigeria: A comparison of military rule and civil rule (1985-2007). An M.Sc. Dissertation Department of Public Administration and Local Government University of Nigeria, Nsukka

4. Aziken, E. Ndujihe, C. Akinrefon, D. \& Kumolu, C. (30 June, 2017). "Nigeria: What is restructuring?" Vanguard. Retrieved from: www.vanguardngr.com/2017/06/nigeria-what-isrestructuring/ (10/11/2017).

5. Bello, S. A. (2017). Restructuring Nigeria: A critical analysis. This Day June, $11^{\text {th }} 2017$. Retrieved from: www.thisdaylive.com/index.php/2017/06/11/restruc turing-nigeria-a- critical-analysis/ (12/12/2017).

6. Elster, J. (1986). An introduction to Karl Marx. Cambridge: Cambridge University Press.

7. Elwell, F. (2012). Karl Marx. Macro-sociology: The Study of Socio-cultural Systems.

8. Encarta Dictionary (2009). "Restructuring". Microsoft Encarta Dictionary. Copyrights.

9. Guclu, I. (2014). Karl Marx and Ralf Dahrendorf: A Comparative Perspective on Class Formation and Conflict. Eskişehir Osmangazi Üniversitesi Iibf Dergisi, 9 (2), 151- 167

10. Marx, M. \& Engels, F. (1967). The Communist Manifesto Harmondsworth: Penguin 